\title{
Lung transplantation for suppurative diseases
}

\author{
MN Samano ${ }^{1 *}$, LM Fernandes ${ }^{1}$, LG Abdalla', RHOB Teixeira² ${ }^{2}$ JE Afonso $\mathrm{Jr}^{2}$, SV Campos², DS Ferronatto ${ }^{3}, \mathrm{~L}$ Turaça ${ }^{3}$, \\ PM Pêgo Fernandes ${ }^{1}$, FB Jatene ${ }^{4}$
}

From 23rd World Congress of the World Society of Cardio-Thoracic Surgeons

Split, Croatia. 12-15 September 2013

\section{Background}

Bronchiectasis may be associated to chronic respiratory failure, whereas lung transplantation (LTx) is the only long term treatment. According ISHLT registries, cystic fibrosis (CF) is the third cause for LTx $(16.8 \%)$ and the best survival in five years (60\%). Non-CF bronchiectasis corresponds to only $2.8 \%$ The aim of this study is to describe our experience with LTx for patients with suppurative diseases.

\section{Methods}

Between 2000 and 2011, the charts of all patients who underwent LTx for suppurative diseases were reviewed.

\section{Results}

Of 150 LTx performed, 59 patients (39.3\%) had suppurative diseases, 29 (19.3\%) were non-CF and 30 (20\%) had CF. In non-CF group, mean age was $40.2 \pm 12.6$ years, male predominance $(58.3 \%)$ and all bilateral. Pulmonary hypertension was present in $50 \%$, but cardiopulmonary bypass (CPB) used $\mathrm{n} 13.8 \%$. None case of PGD3 was seen in this group. CF patients were younger $(27.4+9.2$ years), $53 \%$ males and almost all bilateral (97\%). 30\% had pulmonary hypertension, CPB used in $10 \%$ and $10 \%$ developed PGD3. There were no difference in ventilation time, ICU and hospital stay. The survival rate at 1 and 5 years in CF was $92 \%$ and $77 \%$ and in non-CF was $84 \%$ and $75 \%$. There was no difference according survival but these both groups showed better survival than other underlying diseases $(\mathrm{p}<0.001)$.

\section{Conclusions}

Suppurative diseases are important source of patients for LTx in our program. The incidence of non-CF

\footnotetext{
* Correspondence: marcos.samano@incor.usp.br

${ }^{1}$ Thoracic Surgery Department, Heart Institute (InCor), Hospital das Clínicas da Faculdade de Medicina da Universidade de São Paulo, São Paulo, Brazil Full list of author information is available at the end of the article
}

bronchiectasis is especially high corresponding to the forth indication. The survival rates of these both groups are excellent and comparable to other reports.

\begin{abstract}
Authors' details
'Thoracic Surgery Department, Heart Institute (InCor), Hospital das Clínicas da Faculdade de Medicina da Universidade de São Paulo, São Paulo, Brazil. ${ }^{2}$ Pneumology Department, Heart Institute (InCor), Hospital das Clínicas da Faculdade de Medicina da Universidade de São Paulo, São Paulo, Brazil. ${ }^{3}$ Medical School, University of São Paulo, São Paulo, Brazil. ${ }^{4}$ Thoracic and Cardiovascular Surgery Department, Heart Institute (InCor), Hospital das Clínicas da Faculdade de Medicina da Universidade de São Paulo, São Paulo, Brazil.
\end{abstract}

Published: 11 September 2013

doi:10.1186/1749-8090-8-S1-0238

Cite this article as: Samano et al:: Lung transplantation for suppurative diseases. Journal of Cardiothoracic Surgery 2013 8(Suppl 1):O238.
Submit your next manuscript to BioMed Central and take full advantage of:

- Convenient online submission

- Thorough peer review

- No space constraints or color figure charges

- Immediate publication on acceptance

- Inclusion in PubMed, CAS, Scopus and Google Scholar

- Research which is freely available for redistribution

Submit your manuscript at www.biomedcentral.com/submit
C Biomed Central
C Biomed Central

(c) 2013 Samano et al; licensee BioMed Central Ltd. This is an Open Access article distributed under the terms of the Creative Commons Attribution License (http://creativecommons.org/licenses/by/2.0), which permits unrestricted use, distribution, and reproduction in any medium, provided the original work is properly cited. 